\title{
REGULASI PENYIARAN DIGITAL: DINAMIKA PERAN NEGARA, PERAN SWASTA, DAN MANFAAT BAGI RAKYAT
}

\author{
Digital Broadcast Regulation: Dynamics of Country Role, Private Role, and \\ Benefits for People
}

\author{
Ervan Ismail ${ }^{1}$, Siti Dewi Sri Ratna Sari ${ }^{2}$, Yuni Tresnawati ${ }^{3}$ \\ ${ }^{1}$ Mahasiswa Pascasarjana Komunikasi Pembangunan Pertanian dan Pedesaan IPB Bogor \\ ${ }^{2}$ Mahasiswa Pascasarjana Komunikasi Pembangunan Pertanian dan Pedesaan IPB Bogor \\ ${ }^{3}$ Fakultas Ilmu Komunikasi Universitas Mercu Buana, Jakarta \\ E-mail: ervarismail.ei@gmail.com
}

\begin{abstract}
Digitalization must begin a strong law that is Acts. Based on the records, digital broadcasting regulations using Republic of Indonesia Minister of Communication and Informatics's regulations could be canceled through lawsuits at Supreme Court and State Administration Court. Broadcast digitalization was begun in 2011 through a digitalization Road Map and till date, the process at House of Representatives has not been completed. $85 \%$ of countries in the world have migrated to digital broadcasts. The study aims to describe how changes and various roles in broadcasting digitalization if the revision of the Broadcasting Acts is implemented. The study also aims to find out the impact and benefits of broadcasting digitalization for the public and broadcasting stakeholders compared to present Broadcasting Acts. This study uses participant observation methods and text analysis to categorize the articles of digitalization in the revision draft of the Broadcasting Acts from the House of Representatives Commission I in 2017, accompanied by media coverage analysis. Discourse analysis is used to relate to the problems arised due to broadcast digitalization. The results show that digitalization can provide more channels in the same space than analog broadcasting. Political parties and state institutions will be allowed to have broadcasting institutions. The State through Television Radio of the Republic of Indonesia (RTRI) will become the important player in terrestrial digital broadcasting with a single multiplexer (тих) system, which is considered undemocratic for private television associations. All "television stations" will change and compete to become "content providers" similar to new digital televisions. The government will formulate the mechanisms, socialization, models, roles in digitalizing television broadcasting in a blue print. Digital dividend will be used for the development of internet and telecommunications. The dynamics that occur due to interests' differences of the state, the private sector and society take part at each stage of broadcasting digitalization regulation. The conclusion of the study illustrates that the use of digital technology in broadcasting through the Acts' revision could be a solution for both frequency limitation and the efficient use for more diverse broadcasters (diversity of ownership).
\end{abstract}

Keywords:broadcasting digitalization,broadcasting regulation, broadcasting acts revision, digital television

\begin{abstract}
ABSTRAK
Digitalisasi harus dimulai dengan payung hukum kuat berupa Undang-Undang. Berdasarkan pengalaman, regulasi penyiaran digital menggunakan Permenkominfo RI bisa dibatalkan melalui gugatan di MA dan PTUN. Digitalisasi penyiaran dimulai 2011 melalui Road Map digitalisasi dan proses di badan legislasi DPR-RI sampai sekarang belum selesai. $85 \%$ negara didunia sudah bermigrasi ke siaran digital. Penelitian bertujuan mendeskripsikan bagaimana perubahan dan berbagai peran dalam digitalisasi penyiaran jika revisi UU Penyiaran diberlakukan serta untuk mengetahui dampak dan
\end{abstract}


manfaat digitalisasi penyiaran bagi masyarakat dan stakeholder penyiaran dibandingkan dengan UU Penyiaran yang masih berlaku. Penelitian ini menggunakan metode observasi partisipan dan analisis teks pengelompokkan pasal-pasal digitalisasi dalam draf revisi UU Penyiaran dari Komisi I DPR RI tahun 2017 yang disertai analisis dari pemberitaan media. Analisis wacana digunakan untuk dikaitkan dengan problematika yang bisa muncul akibat digitalisasi penyiaran. Hasil penelitian memperlihatkan digitalisasi bisa menyediakan lebih banyak saluran dalam ruang yang sama ketimbang penyiaran analog.Partai politik dan lembaga negara akan diperbolehkan memiliki lembaga penyiaran. Negara melalui Radio Televisi Republik Indonesia (RTRI) akan menjadi pemain penting penyiaran digital terestrial dengan sistem single multiplexer (mux), yang dianggap tidak demokratis bagi asosiasi televisi swasta.Seluruh "stasiun televisi" akan berubah dan bersaing menjadi "content provider"seperti televisi digital baru. Pemerintah akan menyusun mekanisme, sosialisasi, model, peran dalam digitalisasi penyiaran televisi dalam sebuah blue print. Kelebihan spektrum frekuensi (digital dividend) akan digunakan untuk pengembangan internet dan telekomunikasi. Dinamika yang terjadi akibat perbedaan kepentingan negara, swasta dan masyarakat mengikuti setiap tahapan regulasi digitalisasi penyiaran. Kesimpulan penelitian menggambarkan pemanfaatan teknologi digital bidang penyiaran melalui revisi Undang-undang dapat menjadi solusi untuk keterbatasan frekuensi sekaligus efisiensi penggunaannya bagi penyelenggara penyiaran yang lebih beragam (diversity of ownership).

Kata kunci:digitalisasi penyiaran, regulasi penyiaran, revisi UU Penyiaran, televisi digital

\section{PENDAHULUAN}

Perjalanan panjang digitalisasi penyiaran di Indonesia nampaknya tidak akan berakhir pada Analogue Switch-Off (ASO) tahun 2018 sebagaimana tahapan dalam Road Map TV Digital yang diprogramkan oleh Kemenkominfo RI. Sampai dengan pertengahan tahun 2018 proses pengambilan keputusan tentang payung hukum digitalisasi melalui rumusan RUU Penyiaran masih tertahan di DPR RI. Ketua Komisi I DPR Abdul Kharis Almasyhari menyebut Rancangan Undangundang atau RUU Penyiaran hingga saat ini masih ada dalam pembahasan di Badan Legislasi atau Baleg(Prastiwi, Liputan6.com, 23 Mei 2018).

Anggota Baleg DPR, Luthfi Andi Mufthi, mengatakan saat ini sikap Dewan masih terbelah. "Kemarin pembahasannya berimbang," kata politikus Partai NasDem itu. Ia mengakui frekuensi adalah sumber daya alam yang terbatas sehingga negara harus hadir dalam pengelolaan. Namun, dia melanjutkan, peran sektor swasta tidak bisa dihilangkan. "Boleh negara mengatur frekuensi, tapi tidak boleh membuat swasta menjadi mati." (Triyogo, Tempo.co, 27 Oktober 2017).

"RUU Penyiaran menjadi RUU prioritas DPR. Kita harapkan draft RUU Penyiaran bisa segera diajukan ke rapat paripurna untuk disetujui menjadi RUU inisatif DPR," kata Bambang Soesatyo saat menerima Asosiasi Televisi Siaran Digital Indonesia (ATSDI) di ruang kerja Ketua DPR, Jakarta, Selasa (17/4/2018) (Septianto, Okezone.com, 17 April 2018).

Wacana tentang digitalisasi penyiaran sendiri telah berkembang sejak 2007, karena banyak negara-negara lain seperti Inggris dan Amerika yang sudah memulainya sejak tahun 1998. Menurut Menkopulhukam Wiranto, sudah 85\% negara-negara di dunia saat ini sudah bermigrasi. Sedangkan di Indonesia sendiri, revisi UU Penyiaran belum kunjung selesai. Padahal migrasi ke digital perlu dilakukan secepatnya(Antoni, Sindonews.com, 8 Maret 2018). 
Perkembangan teknologi komunikasi telah disinyalir oleh Everett Rogers (1986), teknologi kunci yang mendasari semua teknologi komunikasi baru adalah elektronik. Teknologi elektronik dewasa ini memungkinkan kita untuk membangun hampir semua jenis perangkat komunikasi yang diinginkan dengan harga tertentu. Salah satu karakteristik khusus pada 1980-an adalah meningkatnya jumlah dan berbagai teknologi komunikasi baru yang mulai tersedia. Fungsi media baru ini utamanya adalah "many-to-many information exchanges". Sifat interaktif mereka dimungkinkan oleh elemen komputer yang terkandung dalam teknologi baru ini. Bahkan, apa yang menandai teknologi komunikasi baru dari era pasca-1980 secarakhusus bukan hanya ketersediaan teknologi baru seperti mikrokomputer dan satelit, tetapi kombinasi dari elemen-elemen ini dalam jenis sistem komunikasi yang sepenuhnya baru.

Langkah digitalisasi penyiaran dimulai sejak tahun 2007 melalui Permenkominfo No:07/PER/M.KOMINFO/3/2007 tentang Standar Penyiaran Digital Terestrial untuk Televisi Tidak Bergerak di Indonesia. Dilanjutkan dengan Permenkominfo No:39/PER/M.KOMINFO/10/2009 ten-tang Kerangka Dasar Penyelenggaraan Penyiaran Televisi Digital Terestrial Penerimaan Tetap Tidak Berbayar (Free to Air). Kemudian Permenkominfo No:21/PER/M.KOMINFO/4/2009 tentang Standar Penyiaran Digital untuk Penyiaran Radio pada Pita Very High Frequency (VHF) di Indonesia.Selanjutnya Permenkominfo No:22/PER/M.KOMINFO/11/2011 tentang Penyelenggaraan Penyiaran Televisi Digital Teresterial Penerimaan Tetap Tidak Berbayar (Free to Air) yang dibatalkan Mahkamah Agung. Kemudian dilanjutkan dengan Permenkominfo No.32 Tahun 2013 Tentang Penyelenggaraan Penyiaran Televisi Secara Digital dan Penyiaran Multipleksing Melalui Sistem Terestrial. Serta Permenkominfo No.26 Tahun 2014 tentang Perubahan Atas Peraturan Menteri Komunikasi dan Informatika Nomor 32 Tahun 2013 tentang Penyelenggaraan Penyiaran Televisi Secara Digital dan Penyiaran Multipleksing Melalui Sistem Terestrial yang mencabut Permenkominfo sebelum-nya yang dibatalkan MA dan tetap mengakui hasil lelang Multipleksing yang telah ditetapkan sebelumnya(www.kominfo.go.id).

Selanjutnya untuk mendukung aplikasi siaran televisi digital terbit Permenkominfo No. 5 Tahun 2016 tentang Uji Coba Teknologi Telekomunikasi, Informatika dan Penyiaran. Uji coba siaran TV digital dilaksanakan oleh Kementerian Kominfo dengan melibatkan para pemangku kepentingan yaitu KPI, LPP TVRI, penyedia konten dan industri perangkat. Uji coba siaran televisi digital terrestrial bersifat non komersial dan dengan masa laku uji coba selama 6 (enam) bulan dan dapat diperpanjang. Dimana wilayah layanan yang dapat dilakukan uji coba (bahwa telah terbangun infrastruktur multipleksing TVRI) adalah sebanyak 20 lokasi (Ibid).

Dengan sedemikian panjang dan rumitnya perjalanan regulasi Digitalisasi penyiaran tersebut maka jalan satu-satunya yang diharapkan dapat memberikan kepastian hukum dan kekuatan legalitasnya merujuk pada pencantuman digitalisasi pada revisi UU 32 tahun 2002 tentang Penyiaran sebagai jalan keluarnya.

Menarik untuk mencari tahu sejauhmana dinamika digitalisasi penyiaran melalui regulasi dengan mengetahui apa saja isinya yang berkaitan dengan digitalisasi dan konsekuensi yang mengikutinya. Penelitian ini bertujuan untuk 1) Mendeskripsikan bagaimana perubahan dan berbagai peran dalam digitalisasi 
penyiaran jika revisi UU Penyiaran diberlakukan dan 2) Mengetahui dampak dan manfaat dari digitalisasi penyiaran bagi masyarakat dan stakeholder penyiaran dibanding-kan dengan UU Penyiaran yang masih berlaku.

\section{METODE PENELITIAN}

Metodologi yang digunakan berupa analisis isi kualitatif melalui studi kasus yaitu metode riset yang menggunakan sumber data yang bisa digunakan untuk meneliti, menguraikan, dan menjelaskan secara komprehensif berbagai aspek digitalisasi penyiaran di Indonesia. Peneliti menggunakan metode observasi partisipan dan analisis teks pasal-pasal digitalisasi dalam draf revisi UU Penyiaran dari Komisi I DPR RI tahun 2017 yang disertai analisis dari pemberitaan media.

\section{Analisis}

Analisis wacana untuk ilmu komunikasi ditempatkan sebagai bagian dari metode penelitian sosial dengan pendekatan kualitatif. Permasalahan penelitian selalu ditinjau dari perspektif teori komunikasi studi media digital. Analisis wacana sebagai metode penelitian sosial tidak hanya mendalami bahasa (wacana) melainkan pula dikaitkan dengan problematika sosial yang bisa muncul akibat digitalisasi penyiaran.

Proses penelitiannya tidak hanya berusaha memahami makna yang terdapat dalam sebuah naskah, melainkan acapkali menggali apa yang terdapat di balik naskah. Analisis wacana berupaya menerangkan kandungan isi naskah teks revisi UU Penyiaran terkait dengan digitalisasi dan beserta konteks atau historisnya tentang sebuah tema/isu yang dimuat dalam naskah tersebut beserta rangkaian pendapat di media massa.

Pada akhirnya, analisis wacana memang menggunakan bahasa dalam teks untuk dianalisis, tetapi bahasa yang dianalisis bukan dengan menggambarkan semata dari aspek kebahasaan, tetapi juga menghubungkan dengan konteks. Konteks disini berarti bahasa itu dipakai untuk tujuan tertentu dan paktek tertentu, termasuk didalamnya praktek kekuasaan (Eriyanto, 2011:7).

Bagi analisis wacana, titik awalnya adalah bahwa realitas tidak pernah bisa dicapai di luar wacana dan dengan begitu wacana itu sendirilah yang menjadi objek analisisnya. Dalam penelitian analisis wacana yang dilakukan tidaklah memilah-milah pernyataan-pernyataan mana tentang dunia dalam materi penelitian itu yang benar dan mana yang salah (kendati evaluasi kritisnya bisa dilakukan pada tahap belakangan analisis). Sebaliknya, analisis wacana harus menganggap apa yang benar-benar dikatakan atau ditulis dengan cara mengeksplorasi pola-pola yang muncul pada dan lintas pernyataan dan mengidentifikasi konsekuensi-konsekuensi sosial representasi-representasi kewacanaan yang berbeda dari realitas (Jorgensen \& Phillips, 2010:39-40).

\section{Prosedur Penelitian}

Bila kita memiliki lebih dari satu teks tunggal yang ingin kita analisis isinya, saling keterhubungan sintaktik (kohesi), pengonstruksian makna (koherensi), dan fungsinya, maka titik awalnya tentu sama bagi semua peneliti. Mereka sama-sama dihadapkan pada pertanyaan untuk memutuskan teks-teks yang hendaknya mereka kumpulkan dan dari teks yang telah terkumpul itu, teks-teks yang hendak mereka analisis. Dengan demikian, kita tergantung pada: (a) teks-teks yang dihasilkan oleh peneliti untuk menjawab pertanyaan penelitian, (b) materi yang terkumpul 
atau (c) gabungan keduanya. Pada kasus yang pertama, kita berkutat dengan sebuah desain penelitian yang reaktif dan, pada kasus yang kedua, dengan prosedur nonreaktif. Penelitian yang diatur sedemikian rupa sehingga peneliti, melalui teknik pengumpulan datanya, mampu menghilangkan semua pengaruh pada kepada data yang terkumpul secara komparatif masih jarang terjadi dalam ilmu sosial. Contoh dari tipe investigasi yang kedua adalah teks-teks yang telah diterbitkan (artikel di surat kabar, siaran televisi, dan sebagainya) atau tulisantulisan internal seperti dokumen dari organisasi-organisasi (Titscher, dkk, 2009:53).

Bagaimana menemukan materi yang bisa dianalisis melalui urutan teks sebagai representasi dari UU sebagai Regulasi tertinggi - Ciri-ciri dari situasi wacana Digitalisasi - Penyeleksian kelompok atau situasi teks yang berkaitan dengan digitalisasi - Penyeleksian dari seluruh kemungkinan teks yang berkaitan dengan kepentingan rakyat, pemerintah dan swasta dalam digitalisasi identifikasi teks - penetapan unit analisis (Ibid:6). Prosedurnya dimulai dengan mengumpulkan teks draf RUU Penyiaran dari Komisi 1 DPR RI beserta pemberitaan yang terkait, menyeleksi teks yang pasalnya berisi tentang digitalisasi penyiaran. mengelompokkan pola-pola teks yang fokus pada bidang pembahasan tertentu dari digitalisasi.

\section{HASIL DAN PEMBAHASAN}

Dari hasil penelitian terdapat 4 pengelompokkan isu besar dalam draft atau rancangan RUU Penyiaran Komisi 1 DPR RI yang terkait digitalisasi:

1. Definisi dan konsep-konsep penyiaran dalam ketentuan umum.

2. Kelembagaan/Jasa Penyiaran yang nantinya menggunakan teknologi digital terestrial.

3. Mekanisme, model, tata cara, sosialisasi migrasi analog ke digital.

4. Digital dividend dan pemanfaatannya.

Dalam Pasal 1 Ayat 7 Draft RUU tentang Penyiaran disebutkan Digitalisasi Penyiaran adalah seluruh proses perubahan teknologi Penyiaran analog menjadi teknologi Penyiaran digital.

Secara sederhana, digitalisasi penyiaran dapat dijelaskan sebagai proses pengalihan dan kompresi sinyal analog menjadi kode biner. Teknologi ini menawarkan kemungkinan pengaturan frekuensi yang lebih efisien ketimbang teknologi analog. Artinya, penyiaran digital bisa menyediakan lebih banyak saluran dalam ruang yang sama ketimbang penyiaran analog (Dominick dkk, 2012).

Menurut Kemenkominfo RI TV Digital merupakan jawaban dari berbagai perkembangan dalam dunia penyiaran, diantaranya adalah:

1. Urgensi penerapan teknologi penyiaran TV Digital berangkat dari sejumlah permasalahan di sistem penyiaran analog, salah satunya adalah tidak tertampungnya permintaan izin baru frekuensi penyiaran analog.

2. Melalui digitalisasi frekuensi penyiaran, maka efisiensi kanal akan dapat lebih ditingkatkan. Satu kanal frekuensi dengan lebar yang sama yang dengan frekuensi analog dapat menampung program siaran (content provider) yang lebih banyak. Hal ini dapat menjadi solusi atas sejumlah permasalahan. Efisiensi juga terjadi dalam pemakaian daya listrik untuk operasional pemancar. 
3. Penggunaan infrastruktur penyiaran TV siaran analog dinilai tidak efisien karena menara pemancar, antena, saluran transmisi dan sebagainya dimiliki dan dioperasionalkan oleh masing-masing lembaga penyiaran. Diharapkan dengan diterapkannya penyiaran TV digital maka akan terjadi konvergensi.

4. Dengandiimplementasikannya penyiaran digital, wilayah perbatasan Indonesia-Malaysia-Singapura, maka koordinasi penggunaan frekuensi dengan negara lain akan terlaksana dengan lebih baik dan berimbang.

Manfaat Penyiaran Digital:

- Konsumen; kualitas gambar dan suara yang lebih baik, pilihan program siaran yang lebih banyak dan variatif.

- Lembaga Penyiaran; efisiensi infrastruktur dan biaya operasional.

- Industri kreatif; menumbuhkan industri konten.

- Industri perangkat; peluang industri dalam negeri untuk memproduksi set top box dan pesawat televisi digital.

- Pemerintah; efisiensi dan maksimalisasi penggunaan spektrum frekuensi, 1 frekuensi bisa digunakan bersama sampai 12 kanal untuk televisi atau 1 frekuensi bisa sampai 28 kanal untuk radio.

Melalui beberapa tabel berikut akan dideskripsikan isi teks beserta analisis dan pembahasannya.

Tabel 1 Perbandingan Konsep Penyiaran

\begin{tabular}{|l|l|}
\hline UU No. 32 Tahun 2002 tentang & Draft RUU tentang Penyiaran Komisi 1 DPR \\
Penyiaran & RI \\
\hline Ketentuan Umum & Ketentuan Umum \\
Pasal 1 Ayat 2 & Pasal 1 Ayat 2 \\
Penyiaran adalah kegiatan & Penyiaran adalah kegiatan memancarteruskan, \\
pemancarluasan siaran melalui sarana & mengalirkan, dan/atau meyebarluaskan Siaran \\
pemancaran dan/atau sarana transmisi & baik secara satu arah maupun interaktif melalui \\
di darat, di laut, atau di antariksa & sarana pemancaran, pipa, aliran, dan/atau \\
dengan menggunakan spektrum & sarana transmisi di darat, laut, udara, atau \\
frekuensi radio melalui udara, kabel, & antariksa dengan menggunakan spektrum \\
dan/atau media lainnya untuk dapat & frekuensi radio melalui terestrial, kabel dan \\
diterima secara serentak dan & satelit, serta menggunakan internet. \\
bersamaan oleh masyarakat dengan & Ruang Lingkup UU meliputi: \\
perangkat penerima siaran & Pasal 6 \\
& a. Tugas dan wewenang negara; \\
& b. Penyelenggaraan Penyiaran; \\
& c. Penyiaran dengan teknologi digital; \\
d. KPI; \\
e. Lembaga Penyiaran; \\
f. Perizinan; \\
Tujuan & g. P3 dan SPS; \\
Penyiaran diselenggarakan dengan & h. Siaran Iklan; dan \\
tujuan untuk memper-kukuh integrasi & i. Peran serta masyarakat \\
nasional, terbinanya watak dan jati diri & benjaga dan memperkukuh persatuan dan \\
bangsa yang beriman dan bertakwa, & c. Memaga keutuhan NKRI \\
mencerdas-kan kehidupan bangsa, & beriman dan bertakwa \\
memajukan kesejahteraan umum, & d. Meningkatkan harkat, martabat, dan citra \\
dalam rangka membangun masyarakat & bangsa \\
yang mandiri, demokratis, adil dan & e. Menumbuhkembangkan kearifan lokal, \\
\hline
\end{tabular}


sejahtera, serta menumbuhkan industri penyiaran di Indonesia. kecintaan, kebanggaan, kejuangan, dan

kontribusi terhadap NKRI

f. Mencerdaskan kehidupan bangsa

g. Memelihara dan mengembangkan kebiudayaan nasional

h. Meningkatkan kesadaran, kepatuhan, dan tanggungjawab hukum

i. Meningkatkan demokrasi

j. Mendorong peran aktif masyarakat dalam pembangunan

k. Menumbuhkembangkan kreativitas masyarakat yang positif dan produktif

1. Memenuhi kebutuhan masyarakat akan informasi, pengetahuan, dan hiburan serta meningkatkan kemampuan literasi media masyarakat

m. Menumbuhkembangkan Lembaga Penyiaran yang produktif dalam iklim usaha penyiaran yang sehat

n. Melindungi keberadaan Lembaga Penyiaran dalam rangka meningkatkan daya saing di era Penyiaran global

o. Mendorong kemampuan menguasai dan mengadaptasi teknologi Penyiaran terhadap kemajuan teknologi informasi dan komunikasi

Dari tabel tersebut terlihat jelas perubahan terminologi penyiaran yang menambahkan kalimat "menggunakan internet" yang sebelumnya tidak ada di UU Penyiaran. Demikian pula ditambahkannya Ruang Lingkup yang secara jelas mencantumkan "penyiaran dengan teknologi digital" pada huruf c. Demikian pula dalam bagian Tujuan dalam Draf RUU Penyiaran pada huruf $p$ berbunyi mendorong kemampuan menguasai dan mengadaptasi teknologi penyiaran terhadap kemajuan teknologi informasi dan komunikasi.

Tabel 2 Penyiaran dengan Teknologi Digital Terestrial

\section{Pasal 12}

Penyelenggaraan Jasa Penyiaran dilaksanakan dengan memanfaatkan perkembangan teknologi digital.

Pasal 13

Pemanfaatan perkembangan teknologi digital dalam bidang Penyiaran ditujukan untuk meningkatkan kualitas penyelenggaraan penyiaran dan kualitas tayangan siaran bagi masyarakat serta efisiensi frekuensi bagi negara.

Kualitas tayangan siaran yang membawa manfaat bagi masyarakat dapat ditinjau dari dua aspek:

1. Kualitas penerimaan audio-visual yang lebih bersih dan tajam gambarnya, lebih jernih suaranya dan bisa dikombinasikan dengan layanan data (datacast) yang interaktif.

2. Kualitas yang berkaitan dengan isi dan program siaran yang bermutu, mencerahkan, mencerdaskan, memper-kuat persatuan, membina karakter dan jati diri bangsa yang beriman dan bertakwa, sebagaimana tujuan dari penyiaran itu sendiri. 
Everett Rogers (1986:4-6)menyatakanbahwaapa yang berbeda tentang komunikasi manusia sebagai hasil dari teknologi-teknologi baru, karena semua sistem komunikasi baru memiliki tingkat interaktivitas tertentu, media baru tersebut juga demasifikasi (de-massified)dan tidak sinkron (asynchronous).

Interaktivitas adalah kemampuan sistem komunikasi baru (biasanya komputer sebagai salahsatu elemennya) untuk "merespon balik" pengguna, hampir seperti individu yang berpartisipasi dalam suatu percakapan. Media baru bersifat interaktif dengan cara yang tidak bisa dilakukan oleh media massa tradisional dengan one-to-many, media baru berpotensi menjangkau lebih banyak individu dibandingkanjika mereka hanya bertatap muka, meskipun interaktivitas mereka membuat mereka lebih seperti interaksi antarpribadi. Jadi media baru menggabungkan fitur-fitur tertentu dari baikmedia massa maupun saluran antarpribadi.

Media baru juga demasifikasi (de-massified), hinggasebuahpesan khusus dapat dipertukarkanantaratiapindividu dalam audiens yang luas. Tingkat tinggi demasifikasidari teknologi komunikasi baru tersebut berarti bahwa mereka adalah kebalikan dari media massa. Demasifikasi berarti bahwa kontrol sistem komunikasi massa biasanya bergerak dari produsen pesan ke konsumen media.

Teknologi komunikasi baru juga tidak sinkron (asynchronous), yang berarti mereka memiliki kemampuan untuk mengirim atau menerima pesan pada waktu yang sesuai bagi seorang individu. Asinkronisasi komunikasi berbasis komputer berarti bahwa individu dapat bekerja di rumah pada jaringan komputer dan dengan demikian membuat hari kerja mereka lebih fleksibel. Media baru sering memiliki kemampuan untuk mengatasi waktu sebagai variabel yang mempengaruhi proses komunikasi.

Teknologi transmisi digital juga menyediakan peluang bisnis baru bagi broadcasters, berkat penambahan kemampuan interaktif di bagian penerima. Interaktivitas dapat digunakan untuk layanan pendidikan, layanan informasi elektronik, iklan, perbankan, statistik pemirsa, video on demand, games, dll. Return channel dapat mengambil berbagai bentuk seperti jaringan kabel, saluran serat, saluran telepon, tautan terestrial, dan satelit. Masing-masing memiliki kemampuan dan biaya kinerja yang berbeda, dan masing-masing harus dipilih untuk memenuhi persyaratan layanan interaktif yang dipertimbangkan (Robin dkk, 2000:491).

Tabel 3 Jasa Penyiaran

\begin{tabular}{|l|l|}
\hline UU 32 Tahun 2002 & Draft UU Penyiaran Komisi 1 DPR RI \\
\hline Jasa Penyiaran & Jasa Penyiaran \\
(Pasal 13): & (Pasal 10): \\
\hline a. Lembaga Penyiaran Publik & a. Lembaga Penyiaran Publik \\
b. Lembaga Penyiaran Swasta & b. Lembaga Penyiaran Swasta \\
c. Lembaga Penyiaran Komunitas & c. Lembaga Penyiaran Berlangganan \\
d. Lembaga Penyiaran Berlangganan & d. Lembaga Penyiaran Komunitas \\
& e. Lembaga Penyiaran Khusus \\
\hline & Pasal 14 \\
& Penyiaran dengan teknologi digital \\
& teresterial dilaksanakan oleh Lembaga \\
& Penyiaran: \\
& a. Jasa Penyiaran televisi \\
& b. Jasa Penyiaran radio \\
\hline
\end{tabular}


Dengan sifatnya tersebut maka media baru televisi digital bisa ditonton dimana saja dengan perangkat apa saja serta bisa menggabungkan broadcast dan datacast secara interaktif, bahkan partisipatif dengan sesama penonton lainnya.

Munculnya lembaga penyiaran "baru" jika UU disahkan. Dari yang sebelumnya 4 jenis, bertambah 1 menjadi 5 yaitu Lembaga Penyiaran Khusus yang akan diisi oleh lembaga negara, kementerian/lembaga, partai politik, dan pemerintah daerah. Catatan khusus yang menonjol adalah diperbolehkannya partai politik memiliki lembaga penyiaran televisi/radio.

Mengapa partai politik sangat berkeinginan untuk memiliki lembaga penyiaran sendiri dapat merujuk pada teori media McLuhandalam Littlejohn dan Foss (2009), “...adanya jenis media tertentu seperti televisi mempengaruhi bagaimana kita berpikir tentang dan merespons pada dunia.

Fungsi agenda setting bagi Littlejohn dan Foss (ibid), "Media memiliki kemampuan untuk untuk menyusun isu-isu bagi masyarakat". Secara kritis menurut mereka, "Media adalah pemain utama dalam perjuangan ideologis".

Walter Lippman (ibid) mengatakan bahwa, "Mengambil pandangan bahwa masyarakat tidak merespons pada kejadian sebenarnya dalam lingkungan, tetapi pada "gambaran dalam kepala kita".

Dalam beberapa permohonan pendirian izin penyiaran di KPID DKI (20112017) terdapat proposal dari tokoh-tokoh partai, ormas, lembaga legislatif, lembaga TNI dan sebagainya yang berminat untuk mendirikan stasiun televisi dan radio. Inilah yang nantinya diakomodir dalam Lembaga Penyiaran Khusus.

Tabel 4 Penyelenggaraan Penyiaran dengan Teknologi Digital

Pasal 26:

(1) Penyelenggaraan Penyiaran dengan teknologi digital jasa Penyiaran televisi sebagaimana dimaksud dalam pasal 14 huruf a, dilakukan melalui teresterial.

(2) LPS yang menyelenggarakan Penyiaran dengan teknologi digital selain melalui teresterial wajib menjadi LPB.

(3) Dalam hal LPS sebagaimana dimaksud pada ayat (2) tidak menjadi LPB, LPS dikenai sanksi administratif oleh Pemerintah berupa;
a. Teguran tertulis
b. Denda, dan
c. Pencabutan IPP

(4) LPS yang menyelenggarakan penyiaran selain dengan teknologi digital terestrial, mengikuti ketentuan LPB sebagaimana diatur dalam undang-undang ini.

Di Jakarta saja terdapat 48 televisi yang akan bersiaran secara digital, yang terdiri dari 22 Televisi swasta berjaringan (nasional) yang sudah ada ditambah 4 TV lokal dan 4 saluran TVRI beserta penyedia konten yang sudah diberikan Izin Prinsip sebanyak 22 televisi digital baru (ada 18 TV digital Jakarta: Betawi TV, RepublikaTV, KTI, NewsTV, GramediaTV, WarnaTV (FadliZon-Gerindra), BBS TV, TempoTV, SportOne, BNTV, DetikTV, MagnaTV, CityTV, JawaPosTV, SmileTV, RIM TV, NusantaraTV (Nurdin Tampubolon-Hanura), dan TV Mu (Muhammadiyah), ditambah 4 TV digital dari Jabar (2) dan Banten (2)). 
Tabel 5 Batas Waktu Pemberlakuan

\begin{tabular}{|l|l|}
\hline UU 32 Tahun 2002 tentang Penyiaran & Draft RUU Penyiaran Komisi 1 DPR \\
\hline Ketentuan Peralihan & Digitalisasi Jasa Penyiaran Televisi \\
Pasal 60 ayat 3 & Pasal 15 \\
Lembaga Penyiaran yang sudah mempunyai & Batas akhir penggunaan teknologi \\
stasiun relai, sebelum diundangkannya & analog Lembaga Penyiaran jasa \\
Undang-undang ini dan setelah berakhirnya & penyiaran televisi sebagaimana \\
masa penyesuaian, masih dapat & dimaksud dalam Pasal 14 huruf a, \\
menyelenggarakan penyiaran melalui stasiun & paling lambat 3 (tiga) tahun terhitung \\
relainya, sampai dengan berdirinya stasiun & sejak diundangkannya undang- \\
lokal yang berjaringan dengan lembaga & undang ini. \\
penyiaran tersebut dalam batas waktu paling & \\
lama 2 (dua) tahun, kecuali ada alasan khusus & \\
yang ditetapkan oleh KPI bersama pemerintah. & \\
\hline
\end{tabular}

Batas waktu ini seringkali menjadi masalah, karena mengacu pada UU Penyiaran sebelumnya yang memerintahkan penerapan sistem siaran berjaringan dalam aplikasinya tidak bisa jalan sesuai dengan rentang waktu 3 tahun yang diatur dalam pasal Ketentuan Peralihan. Bahkan 10 stasiun televisi bersiaran nasional sampai menjelang akhir 10 tahun masa berlaku IPP nya pada 2016, sistem siaran berjaringan ini masih menyisakan banyak persoalan di daerahdaerah yang hanya "berfungsi" sebagai stasiun relai. Persiapan atau langkah antisipatif progresif sangat diperlukan untuk menegakkan aturan batas akhir penggunaan teknologi analog yang pada awalnya diberlakukan tahun 2018. Sementara di negara-negara lain di dunia sudah $85 \%$ beralih ke teknologi digital(Metrotvnews.com, 8 Maret 2018.).

Demikian pula jika mengacu pada ketentuan International Telecommunication Union (ITU) atau otoritas telekomunikasi internasional telah memberi batas akhir (deadline) kepada seluruh negara di dunia, agar paling lambat, 17 Juni 2015 seluruh lembaga penyiaran melakukan penyiaran dengan digital (Kompas.com, 30 Januari 2012). Jika tidak, maka penyiaran Indonesia bisa saja ketinggalan dan terisolir dari komunitas penyiaran internasional yang sudah terhubung dalam jaringan digital di era industri 4.0.

Tabel 6 Digitalisasi Jasa Penyiaran Radio

Pasal 27:

(1) Digitalisasi jasa Penyiaran radio dilakukan secara alamiah.

(2) Digitalisasi secara alamiah sebagaimana dimaksud pada ayat (1) dilaksanakan melalui pilihan teknologi analog dan teknologi digital secara bersamaan.

(3) Pilihan teknologi sebagaimana dimaksud pada ayat (2) dilaksanakan oleh:

a. Masyarakat;

b. Lembaga Penyiaran jasa Penyiaran radio.

(4) Pilihan teknologi yang dilaksanakan oleh Lembaga Penyiaran jasa Penyiaran radio sebagaimana dimaksud pada ayat (3) huruf b, dilakukan dengan memperhatikan jaminan keberlangsungan usaha Lembaga Penyiaran jasa penyiaran radio.

Pasal 31:

(1) Penyelenggaraan Penyiaran dengan teknologi digital jasa Penyiaran radio sebagaimana dimaksud dalam pasal 14 huruf $b$, dilakukan melalui sistem digital teresterial.

(2) Sistem digital teresterial sebagaimana dimaksud ayat (1) dilakukan berdasarkan pilihan teknologi dengan memperhatikan: 
a. Letak geografis, atau

b. Kebutuhan masyarakat berdasarkan identifikasi program siaran.

(3) Selain pilihan teknologi sebagaimana dimaksud pada ayat (2), sistem digital tereterial dapat menggunakan pilihan teknologi yang sesuai dengan perkembangan teknologi penyiaran.

Pasal 32:

(1) Pilihan teknologi sebagaimana dimaksud dalam pasal 31 ayat (2) ditentukan oleh:
a. Kesiapan masyarakat;
b. Kebutuhan lembaga penyiaran; dan
c. Perkembangan teknologi digitalisasi Penyiaran.

(2) Penggunaan frekuensi Lembaga Penyiaran jasa Penyiaran radio ditetapkan oleh Pemerintah.

Digitalisasi Penyiaran radio dilakukan secara alamiah dari analog ke digital atau secara bersamaan tetap bersiaran analog dan digital (simulcast), sampai nantinya masyarakat dan stasiun radio siap untuk migrasi sepenuhnya ke digital. Pilihan teknologi seperti DAB (Digital Audio Broadcasting) serupa dengan model multiplekser dengan kualitas audio yang bagus setara compact disc dan penggunaan spektrum frekuensi yang efisien. Meskipun isi teks dalam draft RUU Penyiaran tentang radio kurang komprehensif, dengan teknologi digital, radio bisa menjelma menjadi lebih interaktif dengan pendengarnya, bahkan bisa juga secara bersamaan siarannya menayangkan gambar visual selayaknya televisi. Radio juga sudah jauh lebih maju dalam memanfaatkan teknologi, seperti merebaknya radio streaming (melalui internet) yang menjadi alternatif ketiadaan izin frekuensi yang terbatas. Dalam migrasi,penggunaan atau alokasi frekuensinya ditetapkan oleh pemerintah. Mekanismenya bisa merujuk pada pengalaman sebelumnya dimana penyiaran radio pernah bermigrasi dari gelombang AM ke FM.

Tabel 7 Cetak Biru (Blue Print) Peran Pemerintah dalam Digitalisasi

Pasal 16:

(1) Pemerintah memberikan jaminan ketersediaan frekuensi bagi penyelenggaraan Penyiaran jasa Penyiaran televisi sebagaimana dimaksud dalam Pasal 14 huruf a.

(2) Pemerintah wajib menyusun cetak biru penyelenggaraan Penyiaran dengan teknologi digital jasa Penyiaran televisi.

(3) Cetak biru sebagaimana dimaksud pada ayat (2) wajib dilaksanakan oleh Pemerintah.

(4) Cetak biru sebagaimana dimaksud pada ayat (3) terdiri dari pertimbangan:
a. Model migrasi;
b. Penentuan Wilayah Siar;
c. Alokasi frekuensi digital disetiap wilayah Siar
d. Alokasi frekuensi digital untuk Wilayah Siar secara nasional;
e. Kesiapan pemerintah;
f. Kesiapan penyelenggara Penyiaran;
g. Kesiapan produsen perangkat Penyiaran (antara lain televisi digital dan radio digital);
h. Kesiapan distribusi alat pendukung teknologi digital (antara lain set top box);
i. Kesiapan masyarakat; dan
j. Iklim usaha yang sehat.

Kewajiban pemerintah untuk menyusun cetak biru (blue print) tentang berbagai mekanisme dan proses dalam migrasi analog ke digital ini menjadi tantangan besar dalam mewujudkannya. Diperlukan pemahaman, benchmark, 
analisis dan strategi yang bisa diterapkan di Indonesia. Misalnya tentang standarisasi transmisi siaran dan kompresi video digital untuk siaran SD atau HD yang digunakan nantinya, yang tentu saja rentan untuk terus terjadi perubahan mengikuti perkembangan teknologi yang berubah cepat. Beberapa negara yang pernah punya pengalaman menarik dalam migrasi analog ke digital ditunjukkan seperti Korea Selatan. Menurut Ketua Korea Communications Commission (KCC) Lee Kyeong-Jaedalam forum pertemuandengan KPID DKI Jakarta di Seoul, Korea Selatan (5 September 2012), KCC terlibat secara penuh dalam proses migrasi analog ke digital di Korea, termasuk urusan kebijakan, sosialisasi dan distribusiset top box kepada masyarakat. Transisi ke TV digital mengungkapkan bahwa para pembuat kebijakan belum bisa menerima kehilangan kemampuan mereka untuk mengorganisir sektor media (Galperin, 2004:287).

Kedua studi kasus (di Inggris dan Amerika) menunjukkan bagaimana perubahan peraturan benar-benar meningkatkan kekuatan negara di beberapa area peraturan sementara berkurang di area peraturan yang lain. Dengan demikian lebih baik berbicara tentang restrukturisasi atau rekonfigurasi negara sebagai konsekuensi utama globalisasi, daripada kembali kepada keadaan semula. Meskipun globalisasi dan dugaan kecenderungan globalisasi untuk menghasilkan konvergensi dalam regulasi, pemerintah negara-negara industri maju terdapat perbedaan satu sama lain untuk menghasilkan tanggapan kebijakan yang berbeda untuk tantangan serupa (Hart, 2006:220).

Tabel 8 Mekanisme Pengelolaan Tahapan Batas Akhir Digitalisasi

Pasal 17:

(1) Selain melaksanakan cetak biru sebagaimana dimaksud dalam Pasal 16 Ayat (3), Pemerintah wajib mengelola tahapan teknis batas akhir penggunaan teknologi analog.

(2) Tahapan teknis batas akhir penggunaan teknologi analog sebagaimana dimaksud pada ayat (1) meliputi:

a. Menyusun rencana peralihan penggunaan teknologi analog menjadi teknologi digital;

b. Membuat perencanaan tentang kebutuhan infrastruktur dan perangkat penerima Siaran;

c. Menyiapkan perencanaan sosialisasi dan distribusi penggunaan perangkat penerima Siaran digital kepada masyarakat;

d. Mengawasi dan mengevaluasi imlementasi batas akhir penggunaan teknologi analog;

e. Menyusun peraturan teknis pelaksanaan mengenai peralihan penggunaan teknologi analog menjadi teknologi digital; dan

f. Menentapkan perencanaan struktur anggaran dalam rangka melaksanakan migrasi dari analog ke digital.

Pasal 18:

(1) Pemerintah membentuk gugus tugas yang melibatkan pemangku kepentingan dalam proses digitalisasi Penyiaran.

(2) Pemerintah melakukan pengawasan terhadap kerja gugus tugas dan melaporkan kepada DPR RI secara berkala.

(3) Pemerintah sebagaimana dimaksud pada ayat (1) merupakan menteri yang menyelenggarakan urusan pemerintahan dibidang komunikasi dan informatika, menteri yang menyelenggarakan urusan pemerintahan di bidang perdagangan, dan menteri yang menyelenggarakan urusan perindustrian.

(4) Ketentuan mengenai susunan organisasi, tugas, fungsi, dan wewenang gugus tugas sebagaimana dimaksud pada ayat (1) diatur dengan Peraturan Presiden. 
Tahapan akhir migrasi dari analog ke digital memerlukan perencanaan dan persiapan yang matang. Misalnya tentang berapa kebutuhan set top box yang harus diproduksi dan disediakan kepada masyarakat pemilik televisi analog hingga batas akhir diberlakukan siaran digital.

Di Jepang pada tahun 2003, pelibatan pihak lain dalam badan Conference for the Promotion of Terrestrial Digital Broadcasting melalui Action Plans mencakup berbagai kegiatan yang dilakukan oleh organisasi nirlaba yang dibentuk oleh para broadcasters dan pabrikan set up box untuk melakukan promosi. Badan ini menjalankan Call Centre dari lembaga outsourcing (dibiayai oleh hibah pemerintah), menerbitkan brosur penjelasan, dan mengelola sistem untuk memberi label set up box di toko-toko, termasuk stiker peringatan berwarna kuning dengan tanggal 2011, untuk ditempel pada televisi analog. Ini adalah sistem sukarela, hanya disetujui setelah banyak dialog tentang perlunya direncanakan penghapusan televisi analog secara bertahap dan tentang kewajiban untuk memberi konsumen informasi yang tepat waktu tentang peralatan yang berpotensi tidak bisa digunakan (Leiva, dkk, 2006:37).

Tabel 9 Sosialisasi Digitalisasi \& Distribusi Set Top Box

Pasal 19

Pemerintah dan LPP wajib:

a. Menyiapkan perangkat penerima Isi Siaran, distribusi perangkat penerima Isi Siaran kepada masyarakat tidak mampu, dan

b. Melakukan sosialisasi penggunaan teknologi digital kepada masyarakat.

Hal yang penting dalam isi teks pasal 19 ini adalah adanya kewajiban pemerintah dan LPP menyiapkan perangkat penerima siaran digital atau set top box kepada kelompok masyarakat yang kurang mampu untuk memiliki pesawat televisi yangdigital ready. Jenis televisi analog lama tetap bisa menerima siaran tv digital dengan menambahkan set top box (perangkat serupa dekoder, konverter atau receiver yang fungsinya menerima siaran/sinyal digital untuk siaran televisi digital sebelum disalurkan lagi ke pesawat televisi yang masih berteknologi analog untuk dapat menerima siaran digital).

Kegiatan ini menjadi semacam program subsidi berupa penyediaan/produksi dan distribusi perangkat kepada kelompok sasaran yang perlu dilaksanakan dengan anggaran dan sumberdaya manusia yang terencana dengan baik agar tepat sasaran dan tepat guna. Ditambah lagi dengan kewajiban melakukan sosialisasi atau kampanye penggunaan siaran digital kepada masyarakat yang tentunya memerlukan tenaga ahli komunikasi, diseminasi informasi, sampai dengan tim teknis seperti bimbingan penggunaan set top box.

Jika merujuk pada pengalaman negara laindalam Taylor (2010), pemerintah AS memainkan peran sentral dalam transisi, termasuk keputusan mahal pada tahun 2005 untuk menyisihkan hampir \$ 1 miliar dolar bagi program kupon untuk membantu rakyatAmerika membeli konverter digital untuk perangkat televisi analog yang lebih kuno (AS 2005). Pada awal 2009, Kongres membuat perubahan pada Digital Television Transition and Public Safety Act 2005 dan menyetujui tambahan \$ 20 juta dolar untuk kampanye mengedukasi publik (AS 2009). Seperti yang dibahas lebih lanjut dalam kesimpulan, keputusan FCC tahun 2008 untuk membolehkan publik menggunakan white space, yaitu ruang spektrum yang tidak terpakai antara saluran yang dirancang untuk mengakomodasi frekuensi umum yang luber ke sistem analog yang kurang tepat, adalah kemenangan besar bagi 
warga dan teguran pedas bagi kepentingan penyiaran yang mapan. Sulit untuk meramalkan perkembangan seperti itu di Kanada, di mana fokus utama dari transisi adalah melindungi kepentingan yang mapan, bukan menjajaki kemungkinan-kemungkinan baru.

Tabel 10 Tata Cara Migrasi Teknologi Analog ke Digital

Pasal 21:

(1) Pemerintah wajib menetapkan tata cara migrasi teknologi analog ke digital yang terdiri dari:

a. Penentuan batas akhir penggunaaan teknologi analog per-wilayah Siar;

b. Penataan alokasi frekuensi dengan persetujuan DPR RI

c. Penetapan standar pelayanan Siaran Digital;

d. Pengaturan batas akhir produksi dan distribusi televisi dengan teknologi analog; dan

e. Penetapan tarif sewa infrastruktur Penyiaran digital.

(2) Penetapan tata cara migrasi sebagaimana dimaksud pada ayat (1) dilakukan dengan memperhatikan jaminan keberlangsungan usaha Lembaga Penyiaran.

(3) Dalam rangka melaksanakan migrasi Penyiaran analog ke digital sebagaimana dimaksud dalam pasal 20 ayat (1) LPP berwenang:

a. Mengelola dan memanfaatkan frekuensi Penyiaran dengan teknologi digital yang dimilikinya; dan

b. Bertindak sebagai pelaksana penyedia infrastruktur Penyiaran digital di setipa wilayah Siar.

(4) LPP dalam menjalankan kewenangannya sebagaimana dimaksud pada ayat (3) huruf $b$, wajib menyediakan infrastruktur Penyiaran digital dan/atau mengakuisisi infrastruktur Penyiaran Lembaga Penyiaran yang telah memiliki IPP di seluruh Wilayah Siar.

(5) Waktu bagi LPP untuk menyediakan infrastruktur Penyiaran digital dan/atau mengakuisisi infrastruktur Penyiaran Lembaga Penyiaran yang telah memiliki IPP sebagaimana dimaksud pada ayat (4) paling lambat 2 (dua) tahun terhitung sejak diundangkannya Undang-Undang ini.

(6) Anggaran penyediaan infrastruktur Penyiaran digital dan/atau akuisisi infrastruktur Penyiaran Lembaga Penyiaran sebagaimana dimaksud pada ayat (5) berasal dari APBN.

Pasal 22:

(1) LPP sebagaimana dimaksud dalam Pasal 20 ayat (3), wajib:

a. Memberikan perlakuan yang sama kepada semua Lembaga Penyiaran di setiap Wilayah Siar;

b. Menyewakan saluran digital sesuai dengan penataan alokasi frekuensi sebagaimana dimaksud dalam Pasal 21 ayat (1) huruf b kepada Lembaga Penyiaran yang telah memiliki IPP; dan

c. Menjamin kualitas penyajian Siaran digital kepada Lembaga penyiaran sesuai dengan standar pelayanan Siaran digital sebagaimana dimaksud dalam Pasal 21 ayat (1) huruf c.

(2) Selain kewajiban sebagaimana dimaksud pada ayat (1), LPP dapat memberikan kesempatan kepada Lembaga Penyiaran yang akan melakukan pengembangan saluran digital di satu Wilayah Siar.

(3) LPP sebagaimana dimaksud pada ayat (1) dan ayat (2) wajib melaporkan kinerjanya secara periodik kepada DPR RI.

(4) Ketentuan lebih lanjut mengenai pemberian kesempatan kepada Lembaga Penyiaran sebagaimana dimaksud pada ayat (2) diatur dengan Peraturan Pemerintah.

Pasal 23:

(1) LPP sebagaimana dimaksud dalam Pasal 20 ayat (3) wajib melakukan kerjasama berupa sewa infrastruktur Penyiaran digital dengan LPS, LPK, dan Lembaga 
Penyiaran Khusus yang sudah memiliki IPP di setiap Wilayah Siar.

(2) Dalam melakukan kerja sama sebagaimana dimaksud pada ayat (1), LPP berpedoman kepada ketentuan sewa infrastruktur penyiaran.

(3) Ketentuan sewa infrastruktur Penyiaran paling kurang terdiri dari:

a. Tata cara pengelolaan sewa infrastruktur siaran, dan

b. Tarif sewa.

(4) Ketentuan lebih lanjut mengenai kerjasama berupa sewa infrastruktur Penyiaran digital sebagaimana dimaksud pada ayat (1) sampai dengan ayat (3) diatur dengan Peraturan Pemerintah.

\section{Pasal 24:}

(1) LPP wajib melakukan evaluasi dan membatalkan kerjasama dengan LPS, LPK, dan/atau Lembaga Penyiaran Khusus sebagaimana dimaksud dalam Pasal 29 ayat (1) yang tidak dapat melakukan Siaran dalam jangka waktu paling lama 6 (enam) bulan sejak kerjasama dilakukan.

(2) LPP dapat membatalkan kerja sama dalam hal IPP LPS, LPK, dan/atau Lembaga Penyiaran Khusus sebagaimana dimaksud pada ayat (1) dicabut oleh Pemerintah atau terjadi pelanggaran dari kerja sama sewa infrastruktur Penyiaran yang diatur lebih lanjut dalam peraturan pemerintah.

Mekanisme kerjasama atau sewa menyewa antara penyelenggara multiplekser dengan lembaga penyiaran swasta, lembaga penyiaran komunitas, atau lembaga penyiaran khusus menjadi persoalan penting yang perlu diantisipasi sejak awal. Siapa yang menentukan tarif sewa? Apakah tarif sama untuk semua penyewa? Dan berbagai kemungkinan tentang hak dan kewajiban lainnya merupakan mekanisme bisnis yang umumnya bersifat dinamis, sehingga bisa kurang fleksibilitasnya jika diatur melalui peraturan pemerintah.

Tabel 11 Model Migrasi Analog ke Digital

Pasal 28

Model migrasi analog ke digital dilakukan oleh:

a. RTRI;

b. LPS yang telah memiliki IPP.

Pasal 29:

(1) RTRI sebagaimana dimaksud dalam Pasal 28 huruf a wajib mengelola dan memanfaatkan frekuensi Penyiaran dengan teknologi digital yang dimilikinya.

(2) Selain mengelola dan memanfaatkan frekuensi dengan teknologi digital sebagaimana dimaksud pada ayat (1), RTRI wajib membuka kesempatan kepada LPS, LPK, dan Lembaga Penyiaran Khusus di setiap wilayah Siar.

(3) Ketentuan lebih lanjut mengenai kewajiban RTRI dalam pengelolaan dan pemanfaatan frekuensi Penyiaran dengan teknologi digital sebagaimana dimaksud pada ayat (2) diatur dalam undang-undang.

Pasal 30:

(1) LPS sebagaimana dimaksud dalam Pasal 28 huruf b wajib mengelola dan memanfaatkan frekuensi Penyiaran dengan teknologi digital yang dimilikinya di satu wilayah Siar.

(2) Selain mengelola dan memanfaatkan frekuensi Penyiaran dengan teknologi digital yang dimilikinya sebagaimana dimaksud pada ayat (1), LPS wajib:

a. Membayar biaya hak penggunaan frekuensi;

b. Aktif melakukan siaran;

c. Menyosialisasikan program kerja Pemerintah yang berkaitan dengan kepentingan rakyat; dan

d. Menyiarkan peringatan dini bencana.

Radio Televisi Republik Indonesia akan menjadi pemain baru yang penting dalam sistem penyiaran digital dengan sistem single multiplexer (mux). Seluruh 
"stasiun televisi" akan berubah menjadi "content provider" karena mereka hanya bisa menyalurkan kontennya melalui penyalur (mux) yang hanya akan diselenggarakan oleh multiplekser negara yaitu RTRI. "Bargaining position" negara akan menguat kembali melalui tangan RTRI sebagai satu-satu sistem pemancar siaran digital secara terestrial kepada perangkat penerima televisi ke rumah-rumah yang bisa langsung menerima siaran digital (tv terbaru) atau yang harus menggunakan set-top-box (tv lama analog). RTRI menjadi lembaga baru yang fokus tugasnya agak berbeda dengan TVRI yaitu mengelola infrastruktur penyiaran.

Tabel 12 Multiplekser (Mux) Tunggal

\begin{tabular}{|c|c|}
\hline UU 32 Tahun 2002 & $\begin{array}{lrl}\text { Draf RevisiUU } & \text { Penyiaran } \\
\text { Komisi } & \text { 1 DPR RI } & \\
\end{array}$ \\
\hline $\begin{array}{l}\text { Perizinan (pasca putusan MK Tahun 2004) } \\
\text { Pasal } 33 \\
\text { Ayat } 1 \\
\text { Sebelum menyelenggarakan kegiatannya lembaga } \\
\text { penyiaran wajib memperoleh izin penyelenggaraan } \\
\text { penyiaran. } \\
\text { Ayat } 4 \text { huruf d } \\
\text { Izin alokasi dan penggunaan spektrum frekuensi radio } \\
\text { oleh Pemerintah atas usul KPI }\end{array}$ & $\begin{array}{l}\text { Model Migrasi Analog ke } \\
\text { Digital } \\
\text { (1) Model migrasi dari } \\
\text { penyiaran analog ke digital } \\
\text { adalah multiplekser } \\
\text { tunggal. } \\
\text { (2) Frekuensi dikuasai oleh } \\
\text { negara dan pengelolaan- } \\
\text { nya dilakukan oleh } \\
\text { Pemerintah. }\end{array}$ \\
\hline $\begin{array}{l}\text { Pasal 34: } \\
\text { (1) Izin penyelenggaraan penyiaran diberikan sebagai } \\
\text { berikut: } \\
\text { a. Izin penyelenggaraan penyiaran radio } \\
\text { diberikan untuk jangka waktu } 5 \text { (lima) tahun } \\
\text { b. Izin penyeleng-garaan penyiaran televisi } \\
\text { diberikan untuk jangka waktu } 10 \text { (sepuluh) } \\
\text { tahun. } \\
\text { (2) Izin sebagaimana dimaksud dalam ayat z (1) huruf } \\
\text { a dan b masing-masing dapat diperpanjang. }\end{array}$ & $\begin{array}{l}\text { (3) LPP bertindak sebagai } \\
\text { penyelenggara } \\
\text { multiplekser. }\end{array}$ \\
\hline
\end{tabular}

Model migrasi multiplekser tunggal berarti hanya ada satu penyelenggara atau penyalur content provider atau penyedia isi siaran. Ini berarti spektrum frekuensi yang dgunakan untuk menyalurkan isi siaran dikuasai dan dikelola sepenuhnya oleh negara, tidak lagi diberikan izin pemanfaatannya kepada pihak swasta. Model seperti ini membuat swasta kehilangan kontrol pemanfaatan alokasi frekuensi berupa Izin Penyelenggaraan Penyiaran (IPP) yang masa berlakunya 5 tahun untuk radio dan 10 tahun untuk televisi yang dapat diperpanjang setiap akhir masa berlakunya sebagaimana pasal 34 UU penyiaran sebelumnya.

Bagi pihak swasta model ini merupakan kemunduran dari konsep demokratisasi penyiaran yang sebelumnya menjadi spirit terbitnya UU Penyiaran pasca reformasi. Menguatnya peran negara bagi sebagian kalangan dianggap mengembalikan rezim kontrol/sensor terhadap kemerdekaan pers atau kebebasan berpendapat. Pihak swasta juga sangat mengkhawatirkan hilangnya kontrol "manajerial" terhadap penggunaan alokasi frekuensi membuat mereka kesulitan untuk memastikan kontinuitas dan kualitas siaran yang akan mereka pancarkan ke pemirsa.Dari sisi valuasi aset, dalam perkiraan pihak swasta (terutama yang sudah go public) akan terjadi penyusutan nilai aset yang cukup 
signifikan nilainya termasuk kehilangan non-material asset berupa kepemilikan frekuensi.

Dalam hal multiplekser tunggal terdapat keberatan para pengelola 10 televisi yang bersiaran jaringan nasional yang tergabung dalam ATVSI (Asosiasi Televisi Swasta Indonesia) dimana Ketua ATVSI, Ishadi SK mengatakan, hingga kini draft RUU Penyiaran masih digodok di Badan Legislasi (Baleg) DPR RI. ATVSI juga dilibatkan dalam penyusunan draft RUU Penyiaran. "ATVSI telah diundang Baleg DPR RI pada tanggal 3 April 2017 untuk memberikan tanggapan dan masukan mengenai beberapa isu penting yang menjadi roh dari RUU Penyiaran," ujar Ishadi. Adanya penerapan sistem hybrid yang merupakan bentuk nyata demokratisasi penyiaran. "Dan ini juga merupakan antitesa dari monopoli (single multiplexer)"(Qodar, Liputan6.com, 4 Mei 2017).

Ishadi SK juga menilai penerapan konsep single mux berpotensi menciptakan praktik monopoli dan bertentangan dengan demokratisasi penyiaran. Dalam konsep tersebut, frekuensi siaran dan infrastruktur dikuasai oleh single mux operator, dalam hal ini LPP RTRI, yang justru menunjukkan adanya posisi dominan atau otoritas tunggal oleh pemerintah yang diduga berpotensi disalahgunakan untuk membatasi pasar industri penyiaran. "Kami tegaskan menolak konsep single mux tersebut. Bisa dilihat bahwa konsep yang sarat dengan praktik monopoli itu jelas-jelas bertentangan dengan Undang-Undang Nomor 5 Tahun 1999 tentang Larangan Praktik Monopoli dan Persaingan Usaha Tidak Sehat, sekalipun hal tersebut dilakukan oleh lembaga yang dimiliki oleh pemerintah," jelas Ishadi. Dia menilai konsep single mux bukan merupakan solusi dalam migrasi TV analog ke digital. Penetapan single mux operator akan berdampak pada LPS eksisting yang akan menghadapi ketidakpastian karena frekuensi yang menjadi roh penyiaran dan sekaligus menjadi jaminan terselenggaranya kegiatan penyiaran dikelola oleh satu pihak saja. Selain itu, ada potensi pemborosan investasi infrastruktur yang sudah dibangun dan menyebabkan terjadinya pemutusan hubungan kerja karyawan stasiun televisi yang selama ini mengelola infrastruktur transmisi. "Solusinya dengan memajukan penyiaran multipleksing yang dilaksanakan oleh LPP dan LPS atau yang dikenal dengan model bisnis hybrid. Konsep hybrid merupakan solusi dan bentuk nyata demokratisasi penyiaran(Ramdhani, Detik.com, 25 September 2017).

Suara yang mendukung isi teks draf RUU Komisi 1 datang dari Asosiasi Televisi Digital Indonesia (ATSDI). LPS televisi Digital memohon kepada anggota Dewan yang terhormat agar dalam merevisi UU Penyiaran azas keadilan harus diutamakan dengan perlakuan yang sama antara konglomerasi perusahaan TV Analog dan LPS Televisi Digital sebagai berikut: Apabila LPS Digital menggunakan Mux dari TVRI maka para pemilik Televisi Analog juga harus menggunakan Mux dari TVRI. Kami dari ATSDI sangat berkeyakinan bahwa Dewan Perwakilan Rakyat RI akan menciptakan iklim yang kondusif dalam kompetisi yang sehat dengan pemberian perlakuan yang sama dan berkeadilan sesuai konstitusi kita dalam mendukung tumbuhnya industri baru penyiaran sebagai bagian dari upaya membangun industri baru, pemilik baru dan konten yang beragam demi pembangunan Indonesia (www.dpr.go.id). Ini artinya sama dengan menyetujui multipleksertunggal dan membuka ruang kompetisi yang baru bagi semua pelaku digitasisasi penyiaran.

Perbedaan tajam dalam wacana multiplekser tunggal yang mengharuskan adaptasi perubahan dalam persaingan baru dalam ekonomi media dikemukakan 140 
oleh Albarran (2015), "Namun, perusahaan-perusahaan yang sedang sukses dapat jatuh ke dalam "perangkap kompetensi". Kemampuan mereka disempurnakan pada tingkat perusahaan setelah perusahaan-perusahaan tersebut berhasil beradaptasi terhadap perubahan besar dalam lingkungan persaingan mereka. Ketika kebutuhan untuk beradaptasi dengan perubahan besar dalam lingkungan persaingan muncul lagi, inersi(kelembaman) dan kurangnya kapasitas serap dapat menghalangi keefektifan adaptasi perusahaan terhadap perkembangan baru. Akhirnya, perusahaan-perusahaan ini akan keluar dari industri.Perkembanganperkembangan ini mendorong perusahaan-perusahaan yang ada untuk bereaksi terhadap teknologi baru, model bisnis, dan pendatang, tetapi juga membawa industri ini ke putaran dinamika kompetitif berikutnya. Perusahaan yang tidak mampu mengelola adaptasinya dengan lingkungan persaingan baru akan diambil alih atau menghentikan aktifitasnya".

Hal yang juga menarik terkait dengan wacana multiplekser tunggal dalam digitalisasi penyiaran adalah ketidaksetujuan pekerja media Aliansi Jurnalis Independen (AJI) dan komunitas penyiaran telah menyuarakan penolakan melanjutkan sistem penyiaran (digital) yang monopolistis, oligarkis, Jakarta sentris, dan jauh dari kepentingan rakyat Indonesia secara umum. Artinya suara AJI telah diadopsi dalam draft UU Penyiaran melalui model Multiplekser tunggal. Menurut AJI dengan Permenkominfo sebelumnya, semua kanal digital yang jumlahnya banyak itu dapat diberikan pemerintah kepada pemodal yang kuat atau pemenang tender, tanpa ada perlindungan yang proposional untuk Lembaga Penyiaran Publik (LPP), Lembaga Penyiaran Lokal (LPL), Lembaga Penyiaran Berjaringan (LBJ), maupun Lembaga Penyiaran Komunitas (LPK). Terbukti kemudian, bahwa yang memenangi tender dan memiliki kanal TV digital akhirnya Lembaga Penyiaran Swasta (LPS) yang selama ini mendominasi sistem penyiaran analog, dengan segala problematika dan perilakunya yang mengecewakan publik (www.aji.or.id).

Melalui Permenkominfo No:22/PER/M.KOMINFO/11/2011 dalam implementasinya sebenarnya sudah menghasilkan pemenang lelang mux yang umumnya adalah stasiun televisi swasta (nasional) yang sudah eksisting. Sebagian dari mereka sudah menyiapkan infrastruktur untuk menjadi penyelenggara mux dan bersiaran secara digital. Artinya model migrasi yang dianut oleh regulasi pemerintah sebelumnya adalah bukan model multiplekser tunggal yang diselenggarakan oleh RTRI (Radio Televisi Republik Indonesia) melainkan model Hybrid Mux dimana TVRI dan LPS bisa masing-masing menjadi penyelenggara multiplekser.

Tabel 13 Kelebihan Spektrum Frekuensi Radio dan Manfaat bagi Rakyat

(1) Kelebihan spektrum frekuensi radio sebagai akibat dari migrasi penyelenggaraan Penyiaran dengan teknologi analog ke teknologi digital dikuasai oleh negara dan digunakan untuk kepentingan penyelenggaraan penyiaran sesuai dengan arah kebijakan Sistem Penyiaran Nasional.

(2) Selain untuk kepentingan sebagaimana dimaksud pada ayat (1) juga digunakan untuk kepentingan pengembangan:

a. Internet untuk kepentingan Penyiaran; dan

b. Telekomunikasi bagi kesejahteraan masyarakat sesuai dengan ketentuan peraturan perundang-undangan.

(3) Kepentingan pengembangan telekomunikasi bagi kesejahteraan masyarakat 
sebagaimana dimaksud pada ayat (2) huruf b diantaranya digunakan untuk:
a. Informasi dan penanganan bencana;
b. Pengembangan pendidikan;
c. Peningkatan kualitas kesehatan masyarakat;
d. Peningkatan kemampuan pertahanan dan keamanan;
e. Peningkatan pelayanan publik;
f. Peningkatan kualitas data kependudukan; dan
g. Cadangan antisipasi perkembangan teknologi.

(4) Kelebihan spektrum frekuensi radio yang digunakan untuk kepentingan sebagaimana dimaksud pada ayat (1) dan ayat 92) diberikan dengan persetujuan DPR RI.

Digital Dividend adalah kelebihan spektrum frekuensi radio sebagai akibat dari migrasi penyelenggaraan Penyiaran. Manakala terjadi penataan frekuensi berupa alokasi frekuensi akan menyisakan ruang kosong frekuensi yang tadinya digunakan oleh televisi analog. KPI berpendapat bahwa apa pun pilihan terhadap pengelolaan penyiaran digital, harus mengedepankan prinsip keadilan, kesetaraan, dan efisiensi yang menjadi tujuan utama dari migrasi digital.

"Efisiensi tersebut diharapkan menghasilkan digital deviden yang dapat dialokasikan untuk penyediaan internet broadband guna pemenuhan hak masyarakat Indonesia akan informasi," kata Ketua KPI Yuliandre Darwis (Okezone.com, 14 Juli 2017).

Digital dividend atau kelebihan spektrum frekuensi akibat pengaturan alokasi akan bernilai ekonomis tinggi. Jika negara mampu memanfaatkannya untuk kepentingan rakyat secara nyata akan membawa berkah tersendiri bagi rakyat, akantetapi menjadi beban biaya operasional tersendiri bagi pemerintah untuk mengoptimalkannya. Namun jika kembali di-“sewa"-kan untuk keperluan telekomunikasi teknologi 4G atau 5G kepada pihak swasta seperti provider seluler akan menghasilkan pendapatan negara trilyunan rupiah. Namun jika tetap dikuasai oleh "pemilik" spektrum frekuensi dari lembaga penyiaran yang lama maka manfaat untuk rakyat menjadi semakin rendah.

\section{KESIMPULAN DAN SARAN}

\section{Kesimpulan}

Berdasarkan pembahasan maka dapat ditarik beberapa kesimpulan berikut:

1. Digitalisasi Penyiaran merupakan peluang untuk mewujudkan berkembangnya demokratisasi penyiaran dalam bentuk keragaman kepemilikan (diversity of ownership) dan keragaman konten siaran (diversity of content) yang menjadi "spirit" pada masa awal reformasi penyiaran di Indonesia melalui UU No.32 tahun 2002 tentang Penyiaran.

2. Digitalisasi Penyiaran dapat meningkatkan kualitas tayangan siaran yang membawa manfaat bagi masyarakat ditinjau dari dua aspek:

a. Kualitas penerimaan audio-visual yang lebih bersih dan tajam gambarnya, lebih jernih suaranya dan bisa dikombinasikan dengan layanan data (datacast) yang interaktif.

b. Kualitas yang berkaitan dengan isi dan program siaran yang lebih bermutu, mencerahkan, mencerdas-kan, memperkuat persatuan, membina 
karakter dan jati diri bangsa yang beriman dan bertakwa, sebagaimana tujuan dari penyiaran itu sendiri.

3. Digitalisasi Penyiaran menciptakan peluang efisiensi penggunaan frekuensi yang menjadi "milik publik" untuk:

a. Tumbuhnya industri penyiaran beserta industri terkait seperti konten, perangkat digital dan lain-lain.

b. Pemanfaatan digital dividend yang bernilai ekonomis tinggi untuk kepentingan dan kesejahteraan masyarakat.

4. Draft RUU Penyiaran versi Komisi 1 DPR RI yang isi teksnya berkaitan dengan Digitalisasi Penyiaran tetap menimbulkan dinamika wacana pro-kontra di kalangan stakeholder penyiaran sendiri yang telah berlangsung sejak regulasi tentang digital dikeluarkan pemerintah tahun 2007. Dinamika wacana pro-kontra terhadap isi teks regulasi masih terus berlanjut sampai di tingkat pembahasan Badan Legislasi DPR-RI.

5. Isu-isu menonjol yang berkaitan dengan dampak dari draft RUU Penyiaran Komisi 1 adalah:

a. Lembaga Penyiaran Khusus yang bisa dimiliki oleh partai politik, lembaga negara, kementerian lembaga atau pemerintah daerah.

b. Model migrasi analog ke digital yang menggunakan multiplekser tunggal.

c. Sosialisasi penyiaran digital, penyediaan dan distribusi set top box.

d. Kelebihan spektrum frekuensi atau digital dividend.

\section{Saran}

Beberapa hal yang dapat menjadi tantangan bagi studi dan praktisi komunikasi pembangunan berkaitan dengan digitalisasi penyiaran ini dimasa depan diantaranya adalah:

1. Bagaimana sosialisasi televisi digital kepada masyarakat, distribusi dan bimbingan penggunaan set top box bagi kelompok penerima subsidi yang merupakan kelompok masyarakat kurang mampu.

2. Bagaimana pemanfaatan Lembaga Penyiaran Komunitas maupun Lembaga Penyiaran Khusus berbasis digital untuk pengembangan masyarakat pedesaan untuk kepentingan pertanian, pariwisata, dan kelautan.

\section{DAFTAR PUSTAKA}

\section{Jurnal}

Hart, Jeffrey A. 2006. The Continuing Role of State Policy. Federal Communications Law Journal, Vol. 58: Iss. 1, Article 8: 215-220.

Leiva, Maria Trinidad Garcia, Michael Starks dan Damian Tambini. 2006. Overview of digital television switchover in Europe, the United States and Japan. Emerald Insight, Vol. 8, Issue: 3, pp. 32-46.

Taylor, Gregory. 2010. Shut-Off: The Digital Television Transition in the United States and Canada. Canadian Journal of Communication, Vol 35 (1): 7-26.

\section{Buku}

Albarran, Alan B., Sylvia M. Chan-Olmsted dan Michael O. Wirth. 2008. Handbook of Media Management and Economics. New Jersey: Lawrence Erlbaum Associates, Inc. 
Dominick, Joseph R., Fritz Messere.dan Barry L. Sherman. 2012. Broadcasting, Cable, the Internet, and Beyond: An Introduction to Modern Electronic Media (Seventh Edition). New York: McGraw Hill.

Eriyanto. 2011.Analisis Wacana: Pengantar Analisis Wacana Teks Media. Yogyakarta: LKiS.

Galperin, Herman. 2004. New Television, Old Politics: The Transition of Digiral $T V$ in the United States and Britain. New York: Cambridge University Press.

Jorgensen, Marianne W.danLouise J.Phillips. 2010.Analisis Wacana: Teori \& Mode. Yogyakarta: PustakaPelajar.

Littlejohn, Stephen W. dan Karen A. Foss. 2009. TeoriKomunikasi, Edisi 9. Jakarta: SalembaHumanika.

Robin, Michael dan Michel Poulin. 2000. Digital Television Fundamentals: Design and Installation of Video and Audio, 2nd Ed.New York: McGraw Hill.

Rogers, Everett M. 1986. Communication Technology: The New Media Society. New York: The Free Press.

Titscher, Stefan, Michael Mayer, Ruth Wodakdan Eva Vetter. 2009. Metode Analisis Teks \& Wacana. Yogyakarta: PustakaPelajar.

\section{Internet}

AliansiJurnalisIndependen. 3 Maret 2014. CabutPeraturanMenteriKominfoNomor 32/2013 atauPidanakanTifatul(https://aji.or.id/read/berita/258/cabutperaturan-menteri-kominfo-nomor-322013-atau-pidanakan-tifatul.html)

Antoni, Ahmad. 8 Maret 2018. 85\% Negara di DuniaSudahBermigrasike TV Digital. Sindonews.com (https://ekbis.sindonews.com/read/1288100/34/85negara-di-dunia-sudah-bermigrasi-ke-tv-digital-1520518770)

Cawidu, Ismail. 9 Juni 2016. UjiCobaSiaran TV Digital Terestrial. SIARAN PERS NO.42/HM/KOMINFO/06/2016

(https://kominfo.go.id/content/detail/7591/siaran-persno42hmkominfo062016-tentang-uji-coba-siaran-tv-digitalterestrial/0/siaran_pers)

Kompas.com. 30 Januari 2012. Menkominfo: Ayo Pindahke TV Digital (https://tekno.kompas.com/read/2012/01/30/1743088/Menkominfo.Ayo.Pin dah.ke.TV.Digital)

Metrotvnews.com. 8 Maret 2018. WirantoTegaskanPentingnyaPerubahan TV Analog ke Digital (http://news.metrotvnews.com/politik/ObzvjY9b-wirantotegaskan-pentingnya-perubahan-tv-analog-ke-digital)

Okezone.com. 14 Juli 2017. KPI: Undang-undang Penyiaran Baru Harus Utamakan Kepentingan Publik (https://news.okezone.com/read/2017/07/ 14/337/1736522/kpi-undang-undang-penyiaran-baru-harus-utamakankepentingan-publik)

Prastiwi, Devira. 23 Mei 2018. DPR pastikan RUU Penyiaran Menjadi RUU Inisiatif pada Masa Ini. Liputan6.com (https://www.liputan6.com/news/ 
read/3535498/dpr-pastikan-ruu-penyiaran-jadi-ruu-inisiatif-pada-masasidang-ini)

Qodar, Nayfisul. 4 Mei 2017. ATVSI Ajukan 7 Poin Penting dalam RUU Penyiaran. Liputan6.com (https://www.liputan6.com/news/read/2941396/ atvsi-ajukan-7-poin-penting-dalam-ruu-penyiaran)

Ramdhani, Jabbar. 25 September 2017. RUU Penyiaran, Konsep Single Mux Operator Dianggap Tak Demokratis. Detik.com (https://news.detik.com/berita/3657878/ruu-penyiaran-konsep-single-muxoperator-dianggap-tak-demokratis)

Septianto, Bayu. 17 April 2018. Bamsoet: RUU PenyiaranMenjadi RUU Prioritas DPR. Okezone.com (https://news.okezone.com/read/2018/04/17/337/ 1887741/bamsoet-ruu-penyiaran-menjadi-ruu-prioritas-dpr)

Triyogo, ArkhelausWisnu. 27 Oktober 2017. Diduga Ada Campur Tangan Pemilik Modal dalam RUU Penyiaran. Tempo.co (https://nasional.tempo.co/read/1027182/diduga-ada-campur-tanganpemilik-modal-dalam-ruu-penyiaran)

Website DPR RI. 13 April 2017. Masukan Asosiasi Televisi Siaran Digital Indonesia (ATSDI) kepada Badan Legislatif (Baled) DPR-RI Terkait Harmonisasi RUU Penyiaran Inisiatif DPR (http://www.dpr.go.id/doksileg/ proses5/RJ5-20170622-111413-3146.pdf) 